\title{
Book Production and the Onset of Modern Economic Growth
}

\section{by Joerg Baten* and Jan Luiten van Zanden** 1}

* University of Tübingen and Univ. Pompeu Fabra, Barcelona

** Utrecht University and International Institute for Social History

JEL: O14, O40, N10

Keywords: Book Produktion, Economic Growth, Human Capital

Joerg Baten, University of Tuebingen (corresponding author) Department of Economics Mohlstrasse 36

72074 Tuebingen, Germany Telephone: +49 (0)7071/2972985

Fax: +49 (0)7071/295119

E-mail: joerg.baten@uni-tuebingen.de
Jan Luiten van Zanden

International Institute Social History Cruquiusweg 31

1019AT Amsterdam, The Netherlands

Telephone: +31206685866

Fax: +31 206654181

E-mail: jvz@iisg.nl 


\begin{abstract}
Endogenous growth theory suggests that human capital formation plays a significant role for the 'wealth and poverty of nations.' In contrast to previous studies which denied the role of human capital as a crucial determinant of for really long-term growth, we confirm its importance. Indicators of human capital like literacy rates are lacking for the period of 14501913; hence, we use per capita book production as a proxy for advanced literacy skills. This study explains how, and to what extent, growth disparities are a function of human capital formation.
\end{abstract}




\section{Introduction}

There is considerable debate about the causes of welfare growth before the Industrial Revolution, and particularly about the role of human capital formation in that process (Acemoglu et al. 2001, Cervellati and Sunde 2005, Galor and Weil 2000). One approach has focused on the demographic regime - i.e. a trade-off between the quantity and quality of children -, arguing that the Industrial Revolution must have been preceded by a switch towards a regime characterized by high human capital formation (Becker, Tamura and Murphy, 1990; Lucas, 2002). However, economic historians have not found evidence for such a demographic regime change in the centuries before 1800. Usually, the 'demographic transition' which inspired these theories is dated in the period after 1870, about one century after the onset of the Industrial Revolution in Great Britain (Mokyr 1990, Clark 2003; but see De Moor and Van Zanden 2005 for an alternative interpretation). In reaction to this, Galor and Weil (2002), Galor and Moav (2002), and Galor (2005) have modeled the initial growth spurt as driven by the positive effects of population growth and population density only, with demographically induced human capital formation having played a major role not before the second Industrial Revolution of the late $19^{\text {th }}$ century. But also the evidence for a rise of human capital formation in the centuries before 1800 is disputed by economic historians, pointing out, for example, that levels of literacy stagnated during the Industrial Revolution (Mokyr 2002, Allen 2003). Their assessment that human capital formation did not play a key role in causing industrialization clearly contradicts the expectations of growth economists.

These studies suffer from the problem that human capital formation is difficult to quantify, in particular for the pre modern period. We propose that book production is better suited to measure a number of aspects of human capital formation than traditional measures such as literacy, i.e. the ability to sign a contract or register. This study is the first to present a time variant proxy for human capital as far back as the late Middle Ages. Moreover, little was previously known about the human capital of countries such as India, China, Indonesia, and 
Japan, for which we present cross-sectional evidence in the last section of this paper. Welfare growth is defined as the growth of real wages, since they can be measured more or less accurately for the 15th through the 19th century for a number of countries (Allen 2001, 2003). For the period of 1820-1913, relatively reliable GDP estimates are available.

Our primary hypothesis is that

(1) human capital formation, as measured by our indicator of book production, can explain differences in economic growth over the period under study.

Furthermore, we test two alternative (or complementary) hypotheses:

(2) Welfare growth was stimulated by intercontinental trade, which provided competitive advantages (Allen 2003).

(3) Growth-enhancing institutions such as those hindering the executive from expropriating capital stimulated early modern welfare growth, perhaps in coevolution with Atlantic trade (Acemoglu et al. 2002).

This paper is structured as follows: the newly created data set and its sources are presented first, including comments on its strengths and limitations. In a series of regression analyses, we then estimate the influence of human capital on welfare growth while controlling for a number of other variables, and take a closer look at the conditional convergence phenomenon. Finally, we address potential endogeneity issues and test the relationship with a hold-out sample.

\section{Data}

Our estimates of the output of printed books are based on the number of titles or editions which appeared in Western Europe between 1454 and 1800. For the details about the data set, there is a longer working paper version (Baten and van Zanden 2006), where we also discuss the questions on book imports and exports, production and consumption. Our individual observation units, "titles " include both first editions and re-editions, the latter being 
publications distinguished from previous editions by changes made in the contents (revised edition) or layout (new edition). To illustrate this, the first printing of Gutenberg's bible is considered an individual title, as is any new edition of that bible, whereas a reprint of exactly the same manuscript would not count as a title as such. The concept of edition and re-edition is important for our study, since it partially solves the problem of weighing books by importance. Books that were considered particularly important for the development of social life (such as religious texts), for the functioning or improvement of institutions, or the transfer of essential scientific knowledge were re-edited, sometimes again and again. Hence, we measure not only the quantity of books, but also their implicit importance as indicated by their re-editions. Real wages are taken from the internet data archive set up and documented by Allen (2001), and hence follow the patterns already described by him (Allen 2003).

\section{Descriptive statistics}

We first discuss the general tendencies observable from the raw data. For the $15^{\text {th }}$ century, Belgium and Italy have the highest levels of book production per capita, overtaken at around 1600 by the Netherlands and Great Britain (gb for short) (Figure 1). This is an important result in itself, because literacy values in England during the Industrial Revolution were previously estimated as relatively modest and stagnant (Mitch 1993). However, such a pessimistic view of human capital formation during the $1750-1850$ period tends to overlook the strong increase which occurred in the centuries before 1750, when Great Britain became one of the most literate countries of Europe. Thus, the higher number of books per capita could have created substantially greater growth capabilities. Germany, the country where Gutenberg invented the moveable type, belonged to the middle group as it had clearly less books per capita than Great Britain or the Netherlands. Belgium displayed an interesting development, starting out from a high level but falling off heavily in relative terms in the 18th century. This is consistent with Vandenbroeke's argument (1985) that the level of literacy may have declined in Belgium in the 
late 18th and the first half of the 19th century. Spain started at similarly low values as Great Britain in the 16th century, and arrived at the lowest overall value in 1750-99. The biggest growth success was Sweden, rising from the lowest value in 1450-1599 to a position on par with Great Britain in the late $18^{\text {th }}$ century. The Swedish and Dutch gained enormously during that period, relative to the Germans, for example, who destroyed their economy in religious wars.

Spain displays consistently low numbers for the entire period. The fact that real wages declined no more than in other European countries might have been due to the availability of land in Spain. Following Allen (2003), when explaining changes in real wages, we use the agricultural land per agricultural population ratio, the idea being that the non-agricultural population could import foodstuffs using their industrial or service sector income, therefore not pressing on land resources in a Malthusian way. ${ }^{2}$

[Figure 1 around here]

In most countries, real wages declined during this period of rapid population growth (Allen 2003). This stands in a certain contrast to Maddison's estimates of GDP growth, which suggests that inequality was growing enormously (Hoffmann et al. 2002). Only a small portion of the GDP-real wage divergence can be explained by the fact that population moved from the low real wage to high wage regions (such as from rural England to London). Another part of the divergence, some have argued, is caused by the fact that GDP measures the productivity in the modern and urban industrial and commercial sectors, rather than welfare of the whole population (among others, see Koepke and Baten 2005).

Only Great Britain and the Netherlands were able to recover to their late medieval level in the early 18th century, although they lost some ground again thereafter. The heaviest declines occurred in Spain and Italy. France and Germany formed a middle group with relatively modest secular trends, although Germany experienced a strong decline during the 
Thirty Years' War but recovered again later. The Netherlands suffered during the struggle for independence from Spanish rule, but recovered already in the early 17th century. The net effect of these changes was a process of unconditional divergence, with the coefficient of variation almost doubling between the $15^{\text {th }}$ and the $18^{\text {th }}$ centuries.

Table 1 shows the descriptive statistics of the explanatory variables used in the following section. All of them are in logs, except for the dummy variables and intercontinental trade, which follows the original specification chosen in Allen (2003), partly because most values are zeros which would disappear in logarithmic form.

[Table 1 around here]

\section{Regression analyses}

We first run two fixed effects regressions, including dummies for all centuries under study (with the 17th century serving as the reference category), of the econometric form:

$$
\begin{gathered}
{\left[\left(\operatorname{Ln}\left(\mathrm{rw}_{\mathrm{it}}\right)-\operatorname{Ln}\left(\mathrm{rw}_{\mathrm{it}-1}\right)\right]=\right.} \\
\beta_{1} \mathrm{Ln} \mathrm{bo}_{\mathrm{it}-1}+\beta_{2} \mathrm{Ln} \mathrm{rw} \mathrm{it}-1+\beta_{3} \operatorname{tr}_{\mathrm{it}-1}+\beta_{4} \mathrm{cap}_{\mathrm{it}-1}+\sum_{k=1}^{p} \beta_{\mathrm{k}} \mathrm{X}_{\mathrm{kit}-1}+\sum_{n=1}^{q} \beta_{\mathrm{n}} \mathrm{D}_{\mathrm{nit}-1}+\mu_{\mathrm{i}}+\mathrm{u}_{\mathrm{it}}
\end{gathered}
$$

where $\left[\left(\operatorname{Ln}\left(\mathrm{rw}_{\mathrm{it}}\right)-\operatorname{Ln}\left(\mathrm{rw}_{\mathrm{it}-1}\right)\right]\right.$ is the increase of real wages in country $\mathrm{i}$ between the initial half of the century $t-1$ and the current half of the century $t$; Ln bo it- $1_{1}$ equals Log book production (the human capital proxy) in the initial half of the century, with Ln rw it-1 indicating the level of real wages in the initial half of the century in log form, and tr and cap serving as our 'alternative/complementary hypothesis' variables for intercontinental trade and capital-protecting institutional constraints on the executive. $\mathrm{X}$ is a vector of $\mathrm{p}$ control variables such as land per capita, the Thirty Years' War, and similar variables. D is a set of q 
century dummies which control for technological change in book production, the time variant impact of the growth impact per book between centuries, relative price changes, and similar factors. Finally, $\mu_{\mathrm{i}}$ are country fixed effects to control for unobservable country characteristics, and $u_{i t}$ is a stochastic error term. The use of fixed effects models (FE) in dynamic panels has been criticized (Durlauf et al. 2005). But in our case, the three main points of criticism actually support our approach to use the very long run of growth history: The first problem of FE in such panels is that they put much emphasis on the development over time, as opposed to differences between countries. This might be misleading for short time intervals (as the typical 1965-2000 growth studies have). This is clearly an argument for using half-centuries and a long run time frame, in which it actually makes sense to estimate FE. In the same vein, variations over time 1960-2000 might be mainly measurement error, Durlauf mentions the examples inequality and schooling. In our case, we can be reasonably sure that the changes over time reflect true developments. Thirdly, growth theory suggests long-run effects of factors such as human capital, whereas many empirical post-1960 studies focus on the short run. A $10 \%$ increase in schooling or inequality from 1975 to 1980 cannot have too much effect on growth rates 1980-85. Lags (schooling: often 25 years+) are also not considered enough. Again, this is a good argument for considering the very long run.

Since the dependent variable is the real wage growth between the first and the second half of the century, it is unlikely that unit root problems arise (panel unit root tests with such small samples have very limited power). As all explanatory variables refer to the initial half of the century, we avoid contemporaneous correlation problems. Please note that we follow the standard procedure developed by Barro $(1991,1999,2003)$ and many others, who regress growth rates on a set of "growth capabilities" measured in levels. The level of human capital is precisely such a "growth capability", since theory suggests that after controlling for the initial welfare level (which might also proxy a country's capital stock, as Barro (1991) has argued), only countries with high human capital can achieve successive welfare growth. 
Having discussed the international trade of books in the working paper version, we decided to test both the per capita production and consumption of books as indicators of human capital (Table 2). This dual approach allows us to assess the robustness to changes in concept. We find that the influence on real wage growth was statistically significant and substantial, even after controlling for a number of other factors. For example, the effect of an additional standard deviation of book production per capita is $1.3 * 0.32=0.42$. This is quite a large value, given that the standard deviation of real wage growth is only 0.76 . Hence, human capital as measured in books per capita had indeed a strong, positive, and economically significant impact on welfare growth.

Our proxy variable for intercontinental trade which encompasses Atlantic imports and exports per population is insignificant once we control for human capital, conditional convergence effects, and other variables. Moreover, this result is quite robust across various models (see also the regressions below).

The constraints on the executive powers to expropriate capital as defined in Acemoglu et al. (2002) turns out as an important determinant of growth. However, the positive influence of this variable does not change the other results significantly (in spite of some collinearity with our book production indicator, as indicated by the correlation coefficient of 0.56 ). Hence, human capital as proxied by book production might have been an additional factor in the facilitation of welfare growth, independent of the institutional factors (which were also important). We can therefore confirm our introductory hypotheses 1 (human capital) and 3 (institutions protecting capital), whereas we find no confirmation for hypothesis 2 (intercontinental trade).

The level of initial real wages is significantly negative, pointing to the existence of conditional convergence in early modern Europe. We would not put too much emphasis on this finding, given that fixed effects are somewhat biased towards indicating convergernce 
effects (Durlauf et al. 2005). But to a certain extent, this might imply that technology transfer to initially less sophisticated countries (such as Sweden) took place.

Our control variables have mostly the expected sign, such as land per agricultural worker. Particularly this "Malthusian" variable has a remarkably high coefficient, and is statistically significant at the $10 \%$ level. Hence, Malthus was right when he argued that land was a limiting factor for early modern welfare growth, even if he did not take into account the positive counter-forces of human capital accumulation which had reached a critical level during the Industrial Revolution and in the end served to break up the premodern, Malthusian world, as will be shown in the following section.

[Table 2 around here]

Among the control variables, we add a dummy variable for Germany during the Thirty Years' War for obvious reasons, and another for the post-war period (omitting them does not change the other results). Hence, we are able to quantify the effect of the Thirty Year's War on Germany while controlling for the other relevant factors. Real wage growth was substantially lower in the early 17 th century, although this result is only economically, but not statistically significant. The recovery effect after the war was even stronger: in the late 17th century, i.e. after the peace treaty of 1648 , conditional real wage growth increased by more than one percent.

These results are very robust to various specifications (not shown). We also tested the random effects model, but rejected it on the basis of the Hausman test. Nevertheless, even in the random effects specification, books per capita have a significant impact on real wage growth.

Kremer (2001) has argued that initial population size (or initial land area) might impact on technological development in the long run, in particular that technology increases 
more than proportionally with population size. He argues with his "research equation" that the much larger land mass of Eurasia led to its superiority over the Americas, and those over Australia, Tasmania and Flinders island, respectively (hence $\mathrm{N}=5$ ). As a proxy for technological development he uses the availability of single technologies, such as "did those economies already have stone tools", "were they engaged in metallurgy" and so on, and population growth. We cannot satisfactorily test his argument here, as the European countries were much more integrated than Eurasia, the Americas, and Tasmania, which were divided by oceans (and his argument refers to the development over millennia). However, we performed the experiment to include (a) initial population size and (b) the agricultural land area in our regressions, in order not to neglect his influential reasoning. However, those variables turned out insignificant, and their inclusion did not change the significance of our human capital proxy (results available from authors).

[Table 3 around here]

We also need to address the issue of endogeneity. After all, books are a normal good, i.e. consumed more heavily with rising income. One strategy here which was already applied above is to take human capital as levels, and subsequent welfare growth in differences, in order to avoid contemporaneous correlation (and to measure growth capabilities). Péter Földvari (work in progress) found in an annual regression for a similar set of countries that book production Granger-causes real wage, and not vice versa. Moreover, we perform instrumental variable estimations (Table 3), with two instruments: the lag in book production is our first instrument (corresponding to $\mathrm{t}-2$ in the econometric model above, i.e. book production almost one century before the wage development to be explained). As a second instrument, we include Allen's (2003) compilation of literacy rates around 1500 and 1800, and linear interpolations between those dates. How justified are those instruments? Good 
instrumental variables should be correlated with the potentially endogenous variable while not influencing the ultimate dependent variable, except via the potentially endogenous variable. The former is clearly true for both instruments, since both are correlated with initial books per capita. For example, in 1750-1799, for which Allen presents relatively reliable literacy data, the correlation between those variables is 0.80 (p-value 0.03 ), for all centuries the correlation is 0.73 (p-value 0.00 ). The latter is also the case here: since we regard our book variable as a proxy for advanced literacy (plus some storage of/access to knowledge functions), the effect of the interpolated literacy values should go through the same causal channel. The same causality chain further applies to Allen's literacy rates, hence we conclude that both instruments are justified. In order to preclude that our instruments are correlated with the error term, we performed the Sargan test for over-identifying restrictions in a regression with country dummies, and found that with a value of 0.11 (p-value 0.74 ), the Sargan test indicates that our instruments are valid.

\section{Out-of-sample test: can $18^{\text {th }}$ century book production explain GDP growth between 1820 and 1913, as well as the Great Divergence?}

In order to test whether book production can account for economic growth in the $18^{\text {th }}$ century, we perform a partial out-of-sample test of the relation between books per capita and GDP growth, using an enlarged data set which includes a number of non-European countries. Apart from this out-of-sample test, it is also interesting to assess whether the production of knowledge as proxied by book production can explain the 'Great Divergence,' i.e. the fact that Western Europe and North America grew rapidly in the $19^{\text {th }}$ century whereas (previously) highly developed regions such as China and India lagged behind (Pomeranz 2002). In other words, can we predict $19^{\text {th }}$ century growth using $18^{\text {th }}$ century book production estimates? In order to test this idea, the dataset is extended to include a number of countries for which data are available on the second half of the $18^{\text {th }}$ century - some of them European (Ireland, 
Switzerland, Poland, Russia), others non-European (United States, China, Indonesia, Japan and India). ${ }^{3}$

Figure 2 shows the relationship between book production in the second half of the 18th century, and the growth of GDP per capita over the $19^{\text {th }}$ century (the period of 1820-1913), according to Maddison's (2001) estimates.

[Figure 2 around here]

The relationship is quite strong. Per capita book production in Asia was close to zero in the cases of India and Indonesia, and at about 3 per million inhabitants in China. In Japan, books per capita, at almost 7 per million inhabitants, were more than twice as high as in Russia, but still much lower than in Western Europe. Variation within Europe was also large, with the highest levels being attained by the Netherlands (538), Sweden (219), and Great Britain (198); not far behind came the U.S. with 141 books per million inhabitants per year. However, this large variation within Europe does not affect the overall results much. Only China is somewhat of an outlier in Figure 2, but has no greater influence on the relationship between the two variables. Both figures show that a close relationship exists between our measure of human capital formation for the $18^{\text {th }}$ century, and economic performance in the period of the Industrial Revolution and its aftermath. Countries with a low level of human capital formation were unable to participate in the industrialization process which transformed the world economy, whereas countries with a better starting position managed to catch up with Great Britain - or even to overtake it. It is interesting to note that Japan invested heavily in schooling as early as the $18^{\text {th }}$ century, which is evident from the existence of a mass market for books. The high level of schooling in pre-Meiji Japan is also confirmed by other evidence (Hayami and Kitô 1999; see also Van Leeuwen 2007 for the large difference between Japan on the one hand, and Indonesia and India on the other hand). Apparently, Japan's high level of 
education alone was sufficient to make it a successful modernizer, whereas other Asian countries failed to industrialize in the $19^{\text {th }}$ century.

\section{Conclusion}

In this study, we employed the number of books per capita in pre-industrial Europe as a proxy of advanced literacy. It was exactly in the countries in which book production increased fastest that real wages developed systematically better over the centuries before the Industrial Revolution than in countries with lagging human capital formation. We performed a number of tests to counter-check the validity of those results, such as robustness tests, instrumental variable estimations, and controlling for additional variables, but the results remained robust. Therefore, we may conclude that human capital formation as measured in this way had a strong and positive effect on economic performance in the centuries before 1800 .

We also assessed two alternative hypotheses regarding the role of institutions and international (and in particular trans-Atlantic) trade in the growth process. Institutional patterns had a positive and independent effect, whereas an effect of intercontinental trade could not be established. Hence, we were able to confirm our introductory hypotheses 1 (human capital) and 3 (institutions protecting capital), whereas we could not confirm hypothesis 2 (intercontinental trade).

Finally, we assessed the movement of human capital formation and economic growth beyond 1800, until 1913, considering a larger sample of countries. Again, the number of book editions per capita allowed a forecast of countries' subsequent growth capabilities in the century of the Great Divergence. Countries with high levels of human capital formation in the $18^{\text {th }}$ century initiated or participated in the industrialization process of the $19^{\text {th }}$ century, whereas countries with low levels of human capital formation were unable to do so, among them many of today's Less Developed Countries such as India, Indonesia, and China. 


\section{References}

Acemoglu D., S. Johnson and J. Robinson (2001), 'The Colonial Origins of Comparative Development: An Empirical Investigation,' American Economic Review 91-5, pp. $1369-1401$.

Acemoglu, D., S. Johnson and J. Robinson (2002), 'The Rise of Europe: Atlantic Trade, Institutional Change and Economic Growth.' NBER Working Paper 9378.

Allen, R.C. (2001), 'The Great Divergence in European Wages and Prices,' Explorations in Economic History, 38, pp. 411-47.

Allen, R.C. (2003), 'Progress and Poverty in Early Modern Europe,' Economic History Review, LVI-3, pp. 403-443.

Bairoch, P. (1988), Cities and Economic Development: From the Dawn of History to the Present, University of Chicago Press, Chicago.

Barro, R.J. (1991), 'Economic Growth in a Cross Section of Countries,' Quarterly Journal of Economics 106-2, pp. 407-43.

Barro, R.J. (1999), 'Human Capital and Growth in Cross-Section Regressions,' Swedish Economic Policy Review 6-2, pp. 237-77.

Barro, R.J. (2003), 'Determinants of Economic Growth in a Panel of Countries,' Annals of Economics and Finance 4-2, pp. 231-74.

Becker, G.S., K. Murphy and R. Tamura (1990), 'Human Capital, Fertility, and Economic Growth,' Journal of Political Economy 98, pp.12-37.

Cervellati, M. and U. Sunde (2005), 'Human Capital Formation, Life Expectancy and the Process of Development,' American Economic Review 95-5, pp. 1653-72.

Clark, G. (2003), 'The Great Escape: the Industrial Revolution in Theory and in History.' Working Paper University of California, Davis.

Darnton, R. (2002), 'Book production in British India, 1850-1900,' Book History 5, pp. 239262. 
Durlauf, S. et al. (2005), 'Growth Econometrics,' in: Ph. Aghion and S. Durlauf (eds.) Handbook of Economic Growth, North-Holland.

Galor, O. (2005), 'From Stagnation to Growth: Unified Growth Theory,' in: Ph. Aghion and S. Durlauf (eds.) Handbook of Economic Growth, North-Holland.

Galor, O. and O. Moav (2002), 'Natural Selection and the Origin of Economic Growth,' Quarterly Journal of Economics 117, pp. 1133-1192.

Galor, O. and D.N. Weil (2000), 'Population, Technology and Growth: From the Malthusian Regime to the Demographic Transition,' American Economic Review 110, pp. 806828.

Hayami, A., and H. Kitô (1999), 'Demography and Living Standards,' in: A. Hayami, O. Saito and R.P. Toby (eds.), The Economic History of Japan: 1600-1990. Volume I: Emergence of economic society in Japan 1600-1859. Oxford University Press, pp. 213-247.

Isa, Z. (1972), Printing and publishing in Indonesia: 1602-1970. Indiana University.

Koepke, N. and Baten, J. (2005), "The Biological Standard of Living During the Last two Millennia." Review of European Economic History, 9, no. 1: 61-97.

Kremer, M.J. (1993), 'Population Growth and Technological Change: 1,000,000 B.C. to 1990," Quarterly Journal of Economics. August, 1993, pp. 681-716.

Leeuwen, Bas van (2007), Human capital and economic growth in Asia. An historical and quantitative analysis of India, Indonesia and Japan, 1890-2000. Manuscript Ph D thesis, Amsterdam.

Lucas, R. (2002), Lectures on Economic Growth. Cambridge, Mass.: Harvard University Press.

Maddison, Angus (2001), The World Economy: a Millennial Perspective. OECD, Paris. Marker, Gary (1982), 'Russia and the 'Printing Revolution': notes and observations,' Slavic Review 41, pp. 266-284. 
Mitch, D. (1993), 'The Role of Human Capital in the First Industrial Revolution,' in: J.

Mokyr (ed.), The British Industrial Revolution: An Economic Perspective. Westview Press, Boulder.

Mokyr, Joel (1990), The Lever of Riches: Technological Creativity and Economic Progress. New York: Oxford University Press.

Mokyr, Joel (2002), The Gifts of Athena. Historical Origins of the Knowledge Society. Princeton University Press.

Moor, Tine de, and Zanden, J.L van (2005), 'Girlpower. The European Marriage Pattern (EMP) and Labour Markets in the North Sea Region in the Late Medieval and Early Modern Period'. Paper for the workshop 'The Rise, Organization, and Institutional Framework of Factor Markets', Amsterdam 2005.

Pomeranz, Kenneth (2000), The Great Divergence: Europe, China, and the Making of the Modern World Economy, Princeton University Press.

Tsuen-Hsuin, Tsien (1985), Paper and printing. Science and civilization in China, vol. 5. Cambridge: Cambridge University Press.

Vandenbroeke, C. (1985), Sociale Geschiedenis van het Vlaamse Volk. Leuven: Kritak. Zanden, Jan Luiten van (1991), 'The First Green Revolution. The Growth of Production and Productivity in European Agriculture,' Economic History Review XLIV, pp. 215-239. Zanden, Jan Luiten van (2004), 'Common workmen, philosophers and the birth of the European knowledge economy. About the price and the production of useful knowledge in Europe 1350-1800,' paper for the GEHN conference on Useful Knowledge, Leiden, September 2004; revised 12 October 2004. 


\section{Tables}

Table 1: Descriptive statistics of the variables used in the regressions

\begin{tabular}{|c|c|c|c|c|c|}
\hline Variable & Obs & Mean & Std.Dev. & Min & Max \\
\hline \multicolumn{6}{|l|}{ Real Wage } \\
\hline Change & 54 & -0.209 & 0.759 & -1.662 & 1.734 \\
\hline Book Consumption & 54 & 3.886 & 1.253 & 0.399 & 6.248 \\
\hline Book Production & 54 & 3.870 & 1.300 & 0.399 & 6.296 \\
\hline Initial Real Wage & 54 & 5.142 & 1.545 & 2.530 & 7.979 \\
\hline \multicolumn{6}{|l|}{ Land per Agric. } \\
\hline Pop. & 54 & 8.154 & 0.395 & 7.282 & 8.991 \\
\hline Intercont. Trade & 54 & 128.209 & 446.534 & 0.000 & 2726.400 \\
\hline Post-war & 54 & 0.019 & 0.136 & 0.000 & 1.000 \\
\hline 30-Years-War & 54 & 0.019 & 0.136 & 0.000 & 1.000 \\
\hline Capital Protection & 54 & 2.296 & 1.574 & 1.000 & 7.000 \\
\hline Literacy (est.) & 54 & 24.611 & 13.982 & 6.000 & 68.000 \\
\hline
\end{tabular}

Sources: book production/consumption: see text; capital protection: Acemoglu et al. (2002); other variables: Allen (2003). Postwar is 1 for Germany during the half century after the Thirty Years' War. Book production and consumption, as well as intercontinental trade, are per capita. 
Table 2: Two fixed effects regressions of real wage changes, 1450-1849

\begin{tabular}{|c|c|c|c|c|}
\hline \multirow{3}{*}{$\begin{array}{l}\text { Prod. or Cons.? } \\
\text { Books }\end{array}$} & \multirow{2}{*}{$\begin{array}{l}\text { Coeff.(1) } \\
\text { PROD. }\end{array}$} & $\mathrm{p}$-values(1) & \multicolumn{2}{|c|}{ Coeff.(2) p-values(2) } \\
\hline & & & CONS. & \\
\hline & 0.321 & 0.018 & 0.359 & 0.014 \\
\hline Initial Real Wage & -0.665 & 0.000 & -0.679 & 0.000 \\
\hline Intercont. Trade & 0.000 & 0.721 & 0.000 & 0.800 \\
\hline Capital Protection & 0.206 & 0.053 & 0.214 & 0.042 \\
\hline \multicolumn{5}{|l|}{ Land per agric. } \\
\hline Worker & 1.366 & 0.093 & 1.441 & 0.079 \\
\hline Post-war & 1.135 & 0.095 & 1.079 & 0.110 \\
\hline 30-Years-War & -0.948 & 0.149 & -0.998 & 0.127 \\
\hline D $16^{\text {th }}$ & 0.009 & 0.975 & 0.015 & 0.959 \\
\hline $\mathrm{D} 18^{\text {th }}$ & -0.135 & 0.570 & -0.172 & 0.470 \\
\hline D $19^{\text {th }}$ & -0.445 & 0.203 & -0.506 & 0.144 \\
\hline Constant & -9.529 & 0.173 & -10.226 & 0.148 \\
\hline Adj. R-Square & 0.28 & & 0.28 & \\
\hline $\mathrm{N}$ & 54 & & 54 & \\
\hline
\end{tabular}

Notes: The dependent variable is always the first difference between the log real wage of one half century and the next. All explanatory variables refer to the initial half century. Sources: see Table 1. 
Table 3: Controlling for endogeneity and institutions: three IV fixed effects regressions of real wage changes, 1450-1849

\begin{tabular}{|c|c|c|c|c|c|c|}
\hline & Coeff.(1) & $p$-values(1) & Coeff.(2) & $\mathrm{p}$-values(2) & Coeff.(3) & p-values(3) \\
\hline Prod. or Cons.? & PROD. & & CONS. & & PROD & \\
\hline Books & 0.524 & 0.045 & 0.512 & 0.088 & 0.454 & 0.071 \\
\hline Initial Real Wage & -0.899 & 0.000 & -0.901 & 0.000 & -0.927 & 0.000 \\
\hline Intercont. Trade & 0.000 & 0.256 & 0.000 & 0.184 & 0.000 & 0.761 \\
\hline \multicolumn{7}{|l|}{ Capital } \\
\hline Protection & & & & & 0.229 & 0.035 \\
\hline \multicolumn{7}{|l|}{ Land per Agric. } \\
\hline Worker & 0.925 & 0.458 & 0.823 & 0.536 & 1.012 & 0.387 \\
\hline Post-war & 0.741 & 0.301 & 0.687 & 0.342 & 0.678 & 0.314 \\
\hline 30-Years-War & -1.084 & 0.104 & -1.130 & 0.095 & -1.149 & 0.067 \\
\hline D $16^{\text {th }}$ & 0.125 & 0.721 & 0.098 & 0.782 & 0.095 & 0.772 \\
\hline D $18^{\text {th }}$ & -0.321 & 0.201 & -0.357 & 0.167 & -0.271 & 0.253 \\
\hline D $19^{\text {th }}$ & -0.668 & 0.088 & -0.734 & 0.062 & -0.828 & 0.028 \\
\hline Constant & -5.166 & 0.644 & -4.255 & 0.723 & -5.847 & 0.602 \\
\hline Adj. R-Square & 0.19 & & 0.18 & & 0.24 & \\
\hline $\mathrm{N}$ & 48 & & 48 & & 48 & \\
\hline
\end{tabular}

Notes: see Table 1. The instrumental variables for book production and consumption are (a) lagged book production and consumption, and (b) literacy, assuming for 1450-1499 the value of 1500, and interpolating linearly to 1800 , for which direct estimates are available. We avoid using urbanisation proxies for the centuries between 1500 and 1800 , as this could be seen as a separate growth determinant, whereas we want to measure the human capital effect as purely as possible. For Sweden, a value equal to that of Germany is assumed. 


\section{Figures}

Figure 1: Book production in early modern Europe, 1450/99-1750/99 (number of new editions per million inhabitants, log scale of vertical axis)

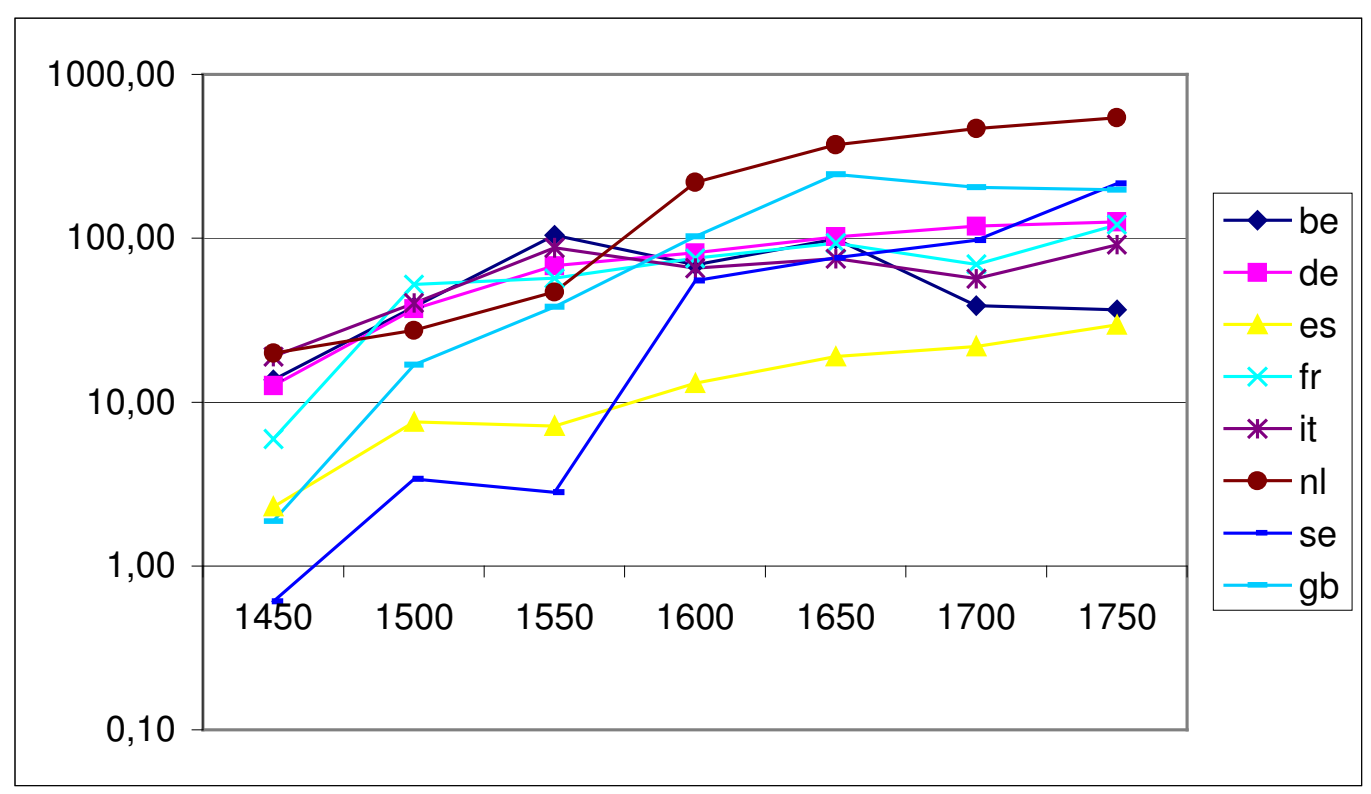

Source: see text. 
Figure 2: Book production per capita between 1750 and 1800, and GDP per capita growth in 1820-1913 (books on log scale)

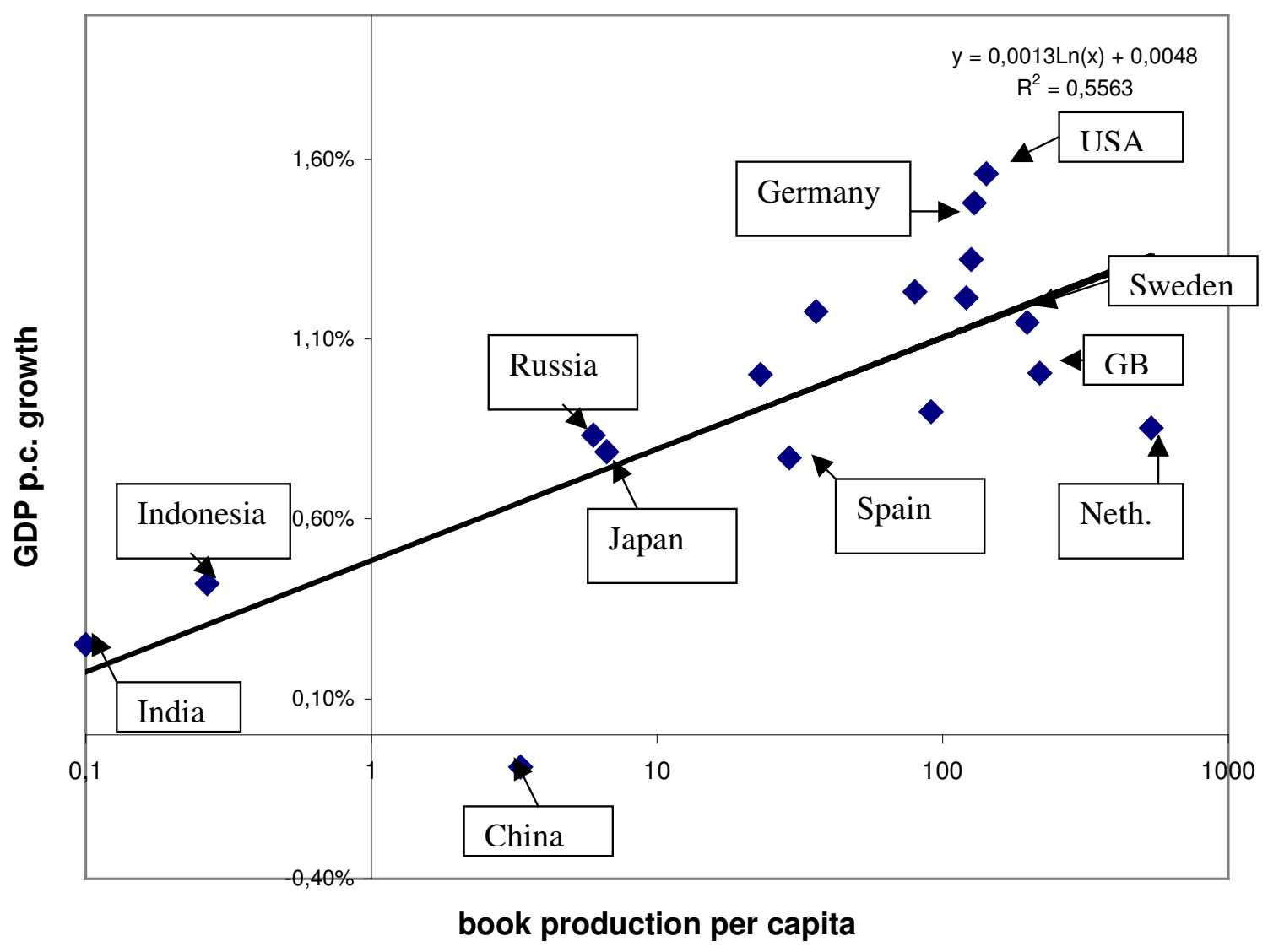




\section{Endnotes}

${ }^{1}$ There are too many people to thank, so that we cannot do justice to everybody. We especially thank Peter Koudijs and Péter Földvari for assistance in the construction of the dataset on book production 1454-1800, and Christiaan van Bochove for constructing a real wage index for Sweden. We also thank the participants of the CEPR Economic Growth Meeting in Venice 2005, the Berlin Colloquium 2006, the Workshop "Biological Welfare and Inequality in Pre-industrial Times: A Political Economy Workshop" in New Haven 2005, for their comments. Particular thanks for comments to Robert Allen, Greg Clark, Dorothee Crayen, Oded Galor, Gerhard Kling, Alexander Moradi, Joachim Voth, and to Frances Rosenbluth, who (co-)organized this latter workshop and the related project, and the YCIASLeitner programme for financial support when Baten was a research fellow at Yale University and worked on this study.

${ }^{2}$ We added this variable also for Sweden, based on a similar procedure as Allen applied it to the other countries: Taking a more recent estimate of agricultural land (van Zanden 1991), and dividing that by the agricultural population. The latter we obtained by subtracting the urban population share as estimated by Bairoch et.al. (1988) for Scandinavia and the nonagricultural rural share (for the latter we assumed that it moved similar to the Polish share also given by Allen) from the total population.

In Western-Europe as a whole average per capita book production increased from less than 10 books per million inhabitants in the 1470 s to 130 books in the 1790 s. This strong increase was closely linked to the falling price of books, which in its turn was caused by economies of scale and learning processes (in the printing industry itself and in paper making), leading to an almost continuous growth in productivity in this industry. Book prices fell by almost $90 \%$ between 1460 and 1800 . The correlation between falling book prices in the Netherlands (the 
international free market for books during much of the early modern period) and book production and consumption was demonstrated in van Zanden (2004).

${ }^{3}$ Sources: for the European countries and the US the same as for the other European countries: USA and Ireland the English Short Title Catalogue, Switzerland, Poland and Russia: the German book fairs in combination with the Hand-pressed book file (for Russia also Marker 1982); Indonesia: Isa 1972; Japan: Hayami and Kitô 1999: 241; China: Tsien Tsuen-Hsiun 1985: 190; India: Darnton 2002; see also the discussion of global patterns of book production in Van Zanden 2004. Because the 1820 estimates of GDP levels for the following test are relatively weak and subject to much debate - with the revisionists claiming that the gap between Europe and China was much smaller than estimated by Maddison (Pomeranz 2002) - we also compare absolute levels of GDP per capita in 1913, and the same book production data for the period of 1750-1800, and found our results confirmed. 